\title{
MUNICIPAL OWNERSHIP AND OPERATION OF STREET RAILWAYS IN GERMANY
}

\author{
By L. S. Rowe, Ph. D.,
}

Professor of Political Science in the University of Pennsylvania.

The introduction of the electric railway marks a turning point in the history of street railway development in Germany. It inaugurated a movement toward municipal ownership and operation which is sweeping over the entire territory of the empire and which includes not only the larger cities, such as Munich, Frankfort, Cologne and Nürnberg, but small towns, such as Bonn, Trier, Colmar and Graudenz. The radical change in public opinion as well as in the attitude of the town authorities toward the question of municipal ownership and operation is due in part to the feeling of antagonism toward the street railway companies; an antagonism traceable to the never ceasing struggle to secure from them something approaching efficient service. A further factor which has exerted no small influence is the fact that the introduction of electricity simplified considerably the conditions of street railway management and made the town authorities less reluctant to assume the burden of this new function. It is a significant fact that during the entire horse railway period but two towns, both of less than ten thousand inhabitantsWiesloch and Friedrichshagen-owned and operated their street railway systems.

The communalization of street railways began in England at a much earlier date than in Germany. As early as I897, forty-two English towns had acquired title to their street railway systems and eight of these, viz: Glasgow, Hull, Huddersfield, Blackpool, Leeds, Sheffield, Plymouth and Birmingham had embarked upon municipal operation. Not until I 898 did one of the larger German citiesFrankfort-commit itself to the principle of municipal ownership and operation.

It may seem surprising at first glance that while the movement for the municipalization of gas plants of German cities began in the 
early sixties, there seemed to be little or no desire to take over the street railways. In 1902, fifty-six of the seventy-three cities with a population of fifty thousand and over, owned and operated their gas plants. The course of development is shown in greater detail in the following table: ${ }^{1}$

Ownership of Gas Plants.

\begin{tabular}{|c|c|c|c|c|c|c|c|}
\hline \multirow{2}{*}{ Cities with Population of } & \multicolumn{2}{|c|}{1868.} & \multicolumn{2}{|c|}{1885.} & \multicolumn{3}{|c|}{1895.} \\
\hline & Private & Munic. & Private. & Munic. & Private. & & nic. \\
\hline $\begin{array}{l}\text { Under } 5,000 \ldots \ldots \ldots \\
\text { Bet. } 5,000-10,000 \ldots \ldots \\
" \quad \text { I0,000-20,000 } \ldots \ldots \\
\text { " } \quad 20,000-50,000 \ldots \ldots \\
\text { Over } 50,000 \ldots \ldots \ldots\end{array}$ & $\begin{array}{l}90 \\
74 \\
66 \\
16 \\
12\end{array}$ & $\begin{array}{l}34 \\
69 \\
45 \\
\text { I } 7 \\
\text { 10 }\end{array}$ & $\begin{array}{l}88 \\
7 \mathrm{I} \\
8 \mathrm{I} \\
33 \\
\mathrm{I} 7\end{array}$ & $\begin{array}{r}36 \\
102 \\
74 \\
4 I \\
29\end{array}$ & $\begin{array}{l}70 \\
83 \\
55 \\
33 \\
13\end{array}$ & $\begin{array}{r}46 \\
\text { I I I } \\
99 \\
76 \\
35\end{array}$ & $\begin{array}{l}(28)^{*} \\
(89) \\
(6 \mathrm{I}) \\
(40) \\
(16)\end{array}$ \\
\hline & $25^{8}$ & I 75 & 290 & 282 & 254 & 367 & $(234)$ \\
\hline
\end{tabular}

* Figures in parenthesis represent the number of cities in which the gas supply was made municipal at the time of its introduction.

The municipal gas plants were successful beyond the expectations of the advocates of municipal ownership. The influence of these municipal plants was not confined to the cities concerned but also served to raise the standard of service in those communities in which the gas service was still in the hands of private companies. In fact, between $185^{\circ}$ and 1890 the efficiency of the most important municipal services, such as water supply, lighting, sanitation and poor relief was raised to a point which placed the cities of Germany in the vanguard of municipal improvement.

In the midst of this general improvement of municipal conditions, urban transportation remained in a most primitive state. In fact it was not until 1865 that the first street railway line was builta short experimental line between Berlin and Charlottenburg. Not until 1872, twenty years after the introduction of street railways in the United States, was the construction of street railway lines on any considerable scale begun. Hamburg had no street railways until I866; Stuttgart until I868; Munich until I876; Cologne until I877; Hamburg until I878; and Nürnberg until I88I. As late as I900 there were still nine cities with a population of 40,000 and over without street railways.

1 For this table, as well as other assistance in the preparation of this article, the author begs to acknowledge his indebtedness to the work of Dr. Hugo Lindemann. "Arbeiterpolitik und Wirtschaftspllege in der Deutschen Staedteverwaltung," Stuttgart, r 904. 
The backwardness of this service was due in great part to the small area of the German cities. The concentration of population within the old city walls made the problem of urban transportation of relatively little importance. Furthermore, the fact that in the German cities of the '7o's and '80's the residence and business sections were not separated, tended to reduce the necessity for improved transit facilities and delayed the development of a true appreciation of the bearing of rapid transit on the improvement of city conditions. It was not until the cities of Germany began to extend their areas through the incorporation of suburban districts that the problem began to assume vital importance. When the city authorities were awakened to the tremendous social value of a well-developed transportation system, they found their hands tied in the attempts to secure it. The franchise grants of the '70's and '80's were generally made for a term of at least twenty-five and in some cases for forty and fifty years. Under the terms of these grants the street railway companies could not be compelled to extend their lines into the suburban districts. The companies were not disposed to take any chances, inasmuch as the original franchise grants imposed heavy financial burdens which would only permit of the construction of lines in the more densely populated sections. The efforts to secure an extension of service from the street railway companies led to long negotiations and gave rise to considerable bitterness of feeling. The only possible solution seemed to be the expropriation of the lines, but this involved expenditures which would have taxed the credit and resources of the larger cities to the utmost and would have been entirely beyond the reach of the smaller cities.

Fortunately the necessity for better service became acute at a time when the street railway companies throughout Germany were applying for the right to change their motive power from horse to electrical traction. The new system was so much more efficient and at the same time so much more economical that no company could afford to forego its use. The city authorities found themselves therefore in an entirely new relation to the companies. Instead of being petitioners for favors, they held the key to the situation. The position of the companies was further weakened by the fact that in most of the larger cities the franchises granted during the seventies had but comparatively few years to run. 
The negotiations between the city authorities and the street railway companies during the period of $1890-1900$ constitute one of the most interesting chapters in the history of German municipalities. The main purpose of the negotiations so far as the cities were concerned, was to secure the construction of additional lines in return for the new privileges. Only after long continued negotiations had demonstrated the impossibility of arriving at an amicable understanding was the desirability of municipalization seriously discussed.

\section{The Steps Towards Municipalization.}

The experience of Frankfort, Munich, Cologne and Nürnberg is typical of the difficulties encountered in bringing about an adjustment to the new conditions and also explains the rapidity with which the movement for municipalization of street railways has spread through the cities of Germany.

In I880 the city of Frankfort granted to a Belgian company the right to operate a railway over certain specified streets. The duration of the franchise was limited to twenty-five years, but the city reserved the right to terminate the contract at the expiration of twelve years and take over all the company's lines. If the city availed itself of this right, the company was entitled to receive, until the expiration of the franchise in 1904, an annual sum equal to 30 per cent. of the average gross income during the three years, I900, I90I and 1902. If the city preferred, this annual payment could be capitalized at 6 per cent. and the entire amount paid in one lump sum. In return for the franchise the company was compelled to pay to the city 5 per cent. of the gross receipts from all lines. As the expiration of this first twelve year period approached it became evident that the sentiment in favor of municipalization was not sufficiently strong to lead to a termination of the contract. On the 24th of March, I89I, the city entered into a new contract with the company. Under its terms the city agreed to extend the franchise until December 3I, I9I4, but reserved the right to terminate the contract and take over the lines either on January I, I898, or on January r, I906. The annual payment of the company to the city was fixed at 6 per cent., with the exception of certain of the new lines which were classed as suburban and from the gross receipts of which the company was only compelled to pay 
3 per cent. The contract provided, furthermore, that the company pay the following sums into the city treasury:

During the first two years of the franchise............ $\$ 7,500$ annually

During the following three years of the franchise......... 10,000

During the following five years of the franchise.......... 12,500

During the following five years of the franchise.......... 15,000

During the following five years of the franchise......... 17,500

During the following five years of the franchise.........20,000

In addition, if the company's accounts showed a net profit exceeding Io per cent. the city was entitled to one-half of such excess. If the net profits exceeded 16 per cent. the city was entitled to twothirds of the excess.

The rapid growth of the city during the first five years of the life of this contract ${ }^{2}$ clearly demonstrated that while the city was receiving a fair return for the use of its streets, the existing lines were totally inadequate to meet the needs of the newer sections of the city. Both branches of the local legislative assembly-the council and the "Magistrat"s determined to use the right to terminate the contract as a weapon to compel the company to construct muchneeded lines in the outlying districts of the city. Although the possibility of placing the street railway system under municipal operation was discussed, the sentiment was not sufficiently strong to make this step seem probable. The negotiations between the company and the city were prolonged but fruitless. The situation was complicated by the fact that the company was anxious to change its motive power from horse to electricity, for which privilege the city was also determined to exact a quid pro quo. The only solution for the deadlock which ensued was the termination of the contract between the city and the company. On November ro, 1896, the city gave notice that it would take over the lines on January I, 1898 . The reluctance of the city authorities was all the greater because the decision involved a heavy financial burden, for under the terms

2 According to the census of 1900 , the population of the city proper was 288,989 , but including the suburban districts within a radius of six miles from the center of the city, which in reality form part of the city, the total population dependent upon the street railway lines of the city amounts to over four hundred thousand $(436,792)$.

"The "Magistrat" of the Prussian cities is one of the organs of local government combining executive with legislative functions. The individual members are the heads of administrative departments. As a legislative body the " Magistrat " occupies a position similar in some respects to that of the upper branch of the American town council. 
of the contract the city had agreed that in case it decided to take over the lines it would pay to the company, until the expiration of the franchise in I9I4, an annual sum equal to 30 per cent. of the average gross income of the years 1895,1896 and 1897 .

Although the street railway lines became the property of the city on the Ist of January, I898, the authorities were unwilling immediately to assume the burdens involved in municipal operation. The "Magistrat" in a report submitted to the council laid special emphasis on the difficulties incident to the change from horse power to electricity, and pointed out that no matter how carefully the change was planned it would certainly cause considerable inconvenience. In these circumstances municipal operation would be introduced under the most unfavorable auspices. In order to avoid this, the city adopted a plan which other German cities have followed, viz: to lease the lines for a brief period to the same company to which the contract for the construction of the electrical equipment was awarded. In 1898 a contract was made with two electrical engineering firms for the transformation of the horse railway into an electrical system and for the construction of a number of additional lines. Under the terms of this contract the operation of the entire railway system was handed over to the construction companies for a term of five years with the reserved right on the part of the city to terminate the contract prior to the expiration of the five year period by giving one year's notice.

The successive steps leading to the municipalization of the street railway system of $\mathrm{Munich}^{4}$ present peculiar interest, owing to the many difficulties and discouragements which the municipal authorities had to face, both in their dealings with the company during the period of private ownership as well as during the first years of municipal ownership.

In I882 the city granted to the Munich Street Railway Company the exclusive right to operate street railways within the city limits. Under the terms of this franchise, the company was required to pave, repair, maintain and clean the section of the street between the rails and sixteen inches to either side thereof. The city reserved to itself the right to do all such paving, repairing and cleaning and to charge the same to the company. The rates of fare to be charged by the company were minutely specified. The lines were divided

4 According to the census of r900, the population of Munich was 499,932. 
into sections of three-fifths of a mile each. For each section the charge was not to exceed one and one-quarter cents, but the company was permitted to fix a minimum fare of two and one-half cents no matter how short the distance travelled. In return for this franchise the company was compelled to make the following annual payments to the city treasury:

I. Of the first $\$ 250,000$ gross receipts, two (2) per cent.

2. Of the succeeding $\$ 12,500$ gross receipts, two and one half (2⿺辶) per cent.

3. On all receipts above $\$ 262,500$ three (3) per cent.

The contract with the company had not been in operation five years before controversies arose between the city and the company relative to the construction of new lines. The desire on the part of the authorities to relieve the congestion in the central sections of the city, combined with the rapid growth of the population, made the extension of existing lines imperative. The company was unwilling, however, to incur the expense unless the city was prepared to grant terms more favorable than those of the original contract. Negotiations with the company extending over a period of four years having proved fruitless, the "Magistrat"' and council decided to build the new lines. They were not prepared, however, to take over the operation of the new lines and therefore entered into a supplementary contract with the street railway company on the 17 th of February, I892, under which the new lines were handed over to the company to be operated for the account of the city. Under this arrangement the company was permitted first to deduct the cost of operation from the gross receipts. The remainder of the income was then divided as follows: The city first to receive 4 per cent. on the cost of construction, 2 per cent. depreciation charge and a sum equal to 3 per cent. of the gross receipts. The remainder, if any, was then to be divided between the city and the company in the ratio of three to one. This contract of February I7, 1892, had been in operation but a short time when the question of the electrical equipment of the entire system arose. Further negotiations with the company resulted in the signing of the contract of October 25, I897, according to the terms of which the entire street railway system

\footnotetext{
"In the Bavarian cities the "Magistrat" occupies the same position as in Prussia, viz.: exercising both executive and legislative functions. The members of the "Magistrat" are elected by the Council subiect to the confirmation of the Central Government. The members of the Council are elected by the people on restricted suffrage.
} 
became the property of the city. Instead of taking over the operation of the system, it was stipulated that the Munich Street Railway Company should continue to run all the lines until the termination of the original franchise period, viz: July I, I907. Owing to the fact that certain sections of the system were built by the company and certain others by the city, the adjustment of the financial relation during the period, I897-1907, was fraught with considerable difficulty. The agreement as finally reached provides:

First. Inasmuch as the introduction of electricity made much of the old rolling stock worthless it was necessary to make a large outlay for new equipment and cars. Instead of making these purchases from city funds the contract stipulated that all such purchases be made by the company after consulting the city authorities, and that the city return to the company each year the amount thus expended. For the renewal of equipment the contract provided for a "Renewal Fund," which is to receive at least six per cent. of the gross receipts.

Second. The gross receipts from lines built by the city must be paid into the city treasury, in return for which the city guarantees to the company 2 sum sufficient to pay all operating expenses.

Third. The gross receipts from lines built by the company are likewise paid into the city treasury, but in this case the city guarantees to the company not only all operating expenses, but also agrees to pay to the company annually, until 1907 , a sum equal to the gross profits of the year 1896-97, viz.: $\$ 230,804.76$.

Fourth. The contract further stipulates that the company is to receive twenty-five (25) per cent. of the net profits.

As we shall see when we come to consider the financial results of municipal ownership, the contract of the city of Munich with the street railway company, while most profitable to the company, has been a constant drain on the resources of the city. Since I897 the stockholders have enjoyed a guaranteed dividend of I I per cent., with the possibility of a larger dividend if a net profit remains after deducting all fixed charges. Until the close of the fiscal year, 1904-1905, the city treasury has been compelled each year to meet a considerable deficit. The amount of this deficit and the causes thereof will be considered in a subsequent section.

The duration of the original franchises granted to the Cologne Street Railway Company ranged from twenty-five to thirty years, but were made at different periods. The first of these expired in I902, another will expire in I9I6 and still another in 1924. Early in 
the '9o's the city authorities suggested to the company the prolongation of certain existing lines and the construction of a number of new ones, but met with no encouraging response. As in Frankfort and Munich, the situation was further complicated by the desire of the company to secure the right to equip the system with electricity. The popular clamor for improved transportation facilities became so strong that the city decided in 1896 to undertake the construction of five new lines on its own account and to equip the same with electricity. Here a new difficulty presented itself. The original franchises gave to the company the exclusive right to run cars on certain streets. As soon as the resolution of the city council became known, the company gave notice that it would contest the right of the city to construct any lines which would directly or indirectly compete with the lines of the company. To make this threat effective the company immediately applied to the Landgericht of Cologne for an injunction to restrain the city from building the new lines. In a long and carefully reasoned opinion the court held that the city could not, without violating the terms of the franchise, construct any new lines which would compete directly with the existing lines of the company. An appeal was taken by the city to the Oberlandesgericht and finally to the Imperial Supreme Court; but with the same result. These decisions placed the city in a most difficult position. The choice seemed to lie between a policy which meant a complete surrender to the company or one which, by delaying the change from horse traction to electricity, would work great harm to the social and economic welfare of the city.

In view of these difficulties the city council, by resolution of March 3I, I897, decided to take over the entire street railway system provided some arrangement could be made with the company to this effect. A commission was appointed to report a plan. The commission presented a report favorable to city ownership and operation, and on the 2 d of January, I900, a contract with the Cologne Street Railway Company was finally signed under which the city became owner of all the company's lines. It is true that the city had to make great financial sacrifices in order to become master of the situation, but it was felt that a continuation of the antagonism between the company and the city would work incalculable harm to the economic and social welfare of the community. Under the terms of the contract the city agreed to take over all the real estate and 
rolling stock of the company; the former at an appraised value of $\$ 661,795.60$, the latter at an appraised value of $\$ 333,995$. In addition the city agreed to pay to the company in return for the cancellation of the franchises the following sums:

First. From the first of January, I899, to the 3oth of June, I913, $\$ 250,000$ annually.

Second. In addition, the following sums:

For the year $1903 \ldots \ldots \ldots \ldots \ldots \ldots \ldots \ldots \ldots \ldots, \ldots \ldots, 250$

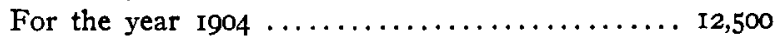

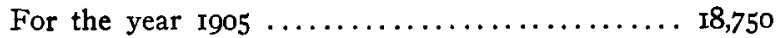

For the year $1906 \ldots \ldots \ldots \ldots \ldots \ldots \ldots \ldots \ldots \ldots \ldots \ldots, 25,000$

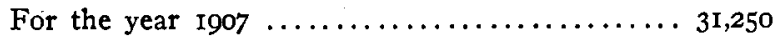

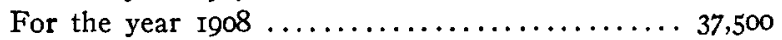

For the year $1909 \ldots \ldots \ldots \ldots \ldots \ldots \ldots \ldots \ldots, 43,750$

For the year $1910 \ldots \ldots \ldots \ldots \ldots \ldots \ldots \ldots \ldots, 50,000$

For the year I9II $\ldots \ldots \ldots \ldots \ldots \ldots \ldots \ldots \ldots \ldots, 56,250$

For the year $1912 \ldots \ldots \ldots \ldots \ldots \ldots \ldots \ldots \ldots 62,500$

For the half year Jan. I to June $30,1913 \ldots \ldots \ldots 34,375$

The contract was given retroactive effect in providing that the lines were to be regarded as belonging to the city from and after the ist of January, I899, but that the company should continue to run the same for the city's account until such time as might be necessary to perfect the organization under city operation. On April first, I900, all the lines were placed under city management. The city was given the privilege, under the contract, to fulfil all its financial obligations towards the company at once by capitalizing the annual payments and making payment of one lump sum. Of this privilege the city has not as yet availed itself.

The first problem confronting the city was to equip the entire system with electricity. In fact, Cologne was the last of the larger German cities to retain horse power and the city authorities therefore felt a special obligation to make the change with all possible speed. Before the close of I9OI the four principal lines were equipped with electricity. The city immediately began to plan the construction of a number of new lines, not only within the city limits, but also to connect the city with the smaller suburban towns. During the fiscal year I902-I903 five new lines within the city limits were constructed, the following year a number of the existing lines were lengthened, and during the year 1903-I9O4 the city took over three existing suburban lines. 
In Nürnberg, as in Frankfort, Munich and Cologne, the communalization of the street railway system was forced upon the community because of the impossibility of securing from the street railway company the kind of service which the rapidly growing city required. The original franchises were granted in I88I for a period of forty years. In 1897 the Nürnberg-Fürther Street Railway Company applied for permission to substitute electricity for horse power. On the I 3 th of August, I897, a new contract was entered into under which the company was given this privilege. In view of the great expense involved in the introduction of the new system, the company made a strong plea for an extension of the franchise beyond I92I. The city finally agreed to an extension of five years, viz: to I926, provided the company would undertake the construction of three new lines.

Within a comparatively short time after the signing of this contract the city authorities began to realize that they had made a serious mistake. Nürnberg was rapidly acquiring a position as one of the leading industrial cities of Germany. Its population was increasing at an extraordinary rate. In I899 a number of suburbs had been incorporated into the city limits and in the immediate vicinity were a number of smaller towns which in fact formed part of the municipal aggregate although not legally a part of the city. It was evident that in order to relieve the congestion of population in the city proper an elaborate system of urban and interurban railways would be necessary. Negotiations were opened with the company with a view to securing such extensions. The company in its reply expressed a willingness to make all the extensions desired, provided the city was willing;-First, to extend the original franchises beyond 1926; and, secondly, to guarantee to the company a net profit on all new lines equal to the average net profit on the lines included in the original franchises.

The apparent one-sidedness of this proposition aroused considerable feeling against the company, which was aggravated by differences growing out of the interpretation of the contract of August I3, 1897. Before the close of 1898 the city authorities were convinced that the only possible solution of the problem lay in the construction of the new lines, either by some other company or by the municipality itself. Negotiations were opened with another company but led to no definite results. The authorities were con- 
vinced by this time that the city would have to build the new lines and be prepared to take over their operation. In December, I90I, application was made to the Bavarian Minister of Internal Affairs for leave to construct and operate certain lines extending both within and without the city limits. In December, I90I, the necessary permission was granted, but objection was immediately filed by the company on the ground that the lines planned would compete directly with existing lines and were, therefore, in violation of the terms of the franchise. The city, in its reply, not only contested the right of the company to make any objection to the proposed lines, but submitted a more elaborate plan involving the construction of a far greater number of lines. In deciding upon this larger plan the city council was influenced mainly by the fact that the territory incorporated within the city limits in I 899 was without adequate transportation facilities. It was hoped that cheap and sanitary workingmen's dwellings would be constructed in these quarters and in order to encourage this larger social purpose the city extended the water, gas and drainage services, and was determined to secure a similar extension of the transportation service. But it was evident that property owners would not be willing to build until an efficient and relatively cheap transportation system was provided.

On the 7 th of July, I902, the Bavarian government gave permission to the city to construct the larger system with the understanding that all questions affecting the rights of the company be settled by the courts. The company had already filed a bill to restrain the city from building the lines, but the suit was brought to a sudden close by the announcement that the city had decided to purchase all the company's lines and that an agreement to this effect had been reached. Under the terms of this agreement, which was ratified by the company on October 20, 1902, the city agreed to pay to the company for the real estate, rolling stock and franchise $\$ 2,835$,$\infty 00, i . e ., \$ 525$ for every share of stock (par value $\$ 250$ ). The payment was made in city bonds bearing 3 per cent. interest. The bonds began bearing interest in January, 1903, but for the year 1902 the city agreed to guarantee to the stockholders a dividend of 8 per cent. The net profits of the year 1902 not being sufficient to pay this dividend, the city was obliged to make up the deficit of $\$ 6,605$.

On the 6th of June, 1903, the entire system passed into the hands of the city. Work on the extension of the lines was immedi- 
ately begun. Before the close of August, 1903, two of the most important lines had been extended to the suburbs of the city. During the fiscal year 1903-I904 over $\$ 80,000$ were expended on new lines. The city also reduced the fares on certain lines for the purpose of relieving the congestion of population in the central districts. Thus, after a long struggle extending over seven years, the city authorities found themselves complete masters of the transportation situation.

\section{The Conditions of Municipal Operation.}

(a) Financial Results.

In considering the results of municipal management, it is important to bear in mind that in all the German cities which have adopted this policy, and particularly the four cities now under consideration, the street railway administration is struggling under exceptionally heavy financial burdens, due in part to the necessity of large outlays for the construction of new, and in the main, unprofitable lines, but mainly owing to the large indemnities which these cities were compelled to pay for the unexpired franchises. A further fact which has had considerable influence is the economic reaction against over-speculation, from which many of the German cities are at present suffering. It is not surprising, therefore, that the first years of municipal management do not show brilliant results.

Of the four larger cities that have embarked upon municipal operation of street railways, the financial situation of the Frankfort system is the most favorable. At the close of the fiscal year r903, after paying all operating expenses, there remained a surplus of $\$ 576,574.25$. Out of this the following fixed charges were paid:

First. Annual payment to street railway company (to be paid each

year until the expiration of the original franchise in 1914) ......\$82,080.00 Second. Interest and liquidation charges on street railway loan.... 140,666.72 Third. Depreciation and renewal fund.................... 56,250.00 Fourth. Contribution to general administrative expenses of the city. 16,816.93

$\$ 295,813.65$

From the remaining $\$ 280,760.60$ the city contributed $\$ 15,805$ toward the pension fund for employees, $\$ 4,0,57.50$ toward the pen- 
sion fund for orphans and widows of employees and $\$ 36,250$ toward the repaving and widening of streets, leaving a net profit of \$224,648. Io. This is by far the most favorable showing since the beginning of municipal operation, the net profits of the preceding years being as follows :

Net Profits.

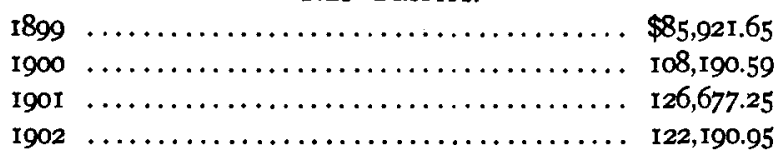

This exceptionally favorable showing was not due to any particularly favorable traffic conditions, but is traceable directly to careful and economical administrative methods.

During the period between 1899 and 1903 the cost of operation per car-mile ${ }^{6}$ was reduced from $13 \frac{1}{2}$ to $83 / 4$ cents. During the same period the percentage of gross receipts required for operating expenses was reduced from 68.29 per cent. to 54.9 per cent. This compares very favorably with the situation in the United States where the relation of operating expenses to gross income for all the electric lines is 57.3 per cent. The following tables will give a clearer idea of the efficiency of municipal management.

RECEIPTS 1899-1903.

\begin{tabular}{|c|c|c|c|c|c|}
\hline Source of Income. & 1890 & 1900 & Ig0I & 1902 & 1903 \\
\hline $\begin{array}{l}\text { Fares ........ . . . .... } \\
\text { Commutation Tickets .. } \\
\text { Forwarding Mail ...... } \\
\text { Miscellaneous ........ }\end{array}$ & $\begin{array}{r}747,829.99 \\
100,610.07 \\
\cdots \times 3,285.73\end{array}$ & $\begin{array}{r}882,616.70 \\
123,282.59 \\
\ldots \ldots \ldots 2, \ldots \\
14,642.93\end{array}$ & $\begin{array}{r}864,619.39 \\
130.443 .75 \\
7.763 .58 \\
16,676.43\end{array}$ & $\begin{array}{r}985,880.20 \\
158,624.62 \\
7,800.97 \\
15,036.22\end{array}$ & $\begin{array}{r}I, 072,505.24 \\
I 70,910.08 \\
7,857.65 \\
28,073.61\end{array}$ \\
\hline $\begin{array}{r}\text { Total } \ldots \ldots \ldots \ldots \\
\text { Receipts per car-mile .. }\end{array}$ & $\begin{array}{c}856,725.79 \\
20 \text { cents }\end{array}$ & $\begin{array}{c}1,020,542,22 \\
\text { rg cents }\end{array}$ & $\begin{array}{l}1,019,503.15 \\
\text { I } 5 t \text { cents }\end{array}$ & $\begin{array}{c}1,167.342 .01 \\
15 \text { cents }\end{array}$ & $\begin{array}{r}\text { I, } 279.346 .58 \\
\text { I } 5 \text { - } 5 \text { cents }\end{array}$ \\
\hline
\end{tabular}

EXPENDITURES I899-1903.

\begin{tabular}{|c|c|c|c|c|c|}
\hline Item. & 1899 & 1900 & I 901 & 1902 & 1903 \\
\hline 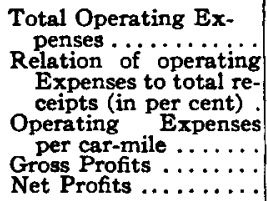 & $\begin{array}{l}\$ 581,667.57 \\
68.29 \% \\
137 \mathrm{cts} . \\
\$ 270,058.21 \\
85.921 .65\end{array}$ & $\begin{array}{c}\$ 620,493.87 \\
60.8 \% \\
\text { Ixt cts. } \\
\$ 400,048.84 \\
106,190.59\end{array}$ & $\begin{array}{l}\$ 633,257.3 \mathrm{I} \\
56.6 \% \\
8 \% \text { cts. } \\
\$ 486,245.84 \\
126,677.25\end{array}$ & $\begin{array}{c}\$ 688,570.10 \\
59 \% \\
\\
9 \text { cts. } \\
\$ 478,771.92 \\
122,190.95\end{array}$ & $\begin{array}{l}\$ 702,772.57 \\
54.9 \% \\
87 \text { cts. } \\
\$ 576,574.25 \\
224,647.50\end{array}$ \\
\hline
\end{tabular}

"The term " car-mile" means the total cost of operating reduced to a unit standard; $i, e$. the cost of operating each car over a distance of one mile. 
Although the receipts per car mile have also declined, this has been due to circumstances which indicate improvement of service rather than decline of traffic. During the five years of municipal operation from 1898 to 1903 the city has constructed a number of new lines in relatively sparsely settled districts, from which no surplus can be expected for some years to come. Although they are certain ultimately to prove profitable, the city has had primarily in view the possibility of influencing the settlement of outlying districts.

We have already had occasion to examine the unfortunate financial situation of the Munich system, due in large part to the extraordinarily heavy payments which the city must make each year to the street railway company as indemnity for the cancelling of the unexpired franchise. The deficit for the fiscal year 1904-I905 amounted to $\$ 32,747.03$, but this is not surprising when we stop to consider that the budget was burdened with the annuity payable to the street railway company, amounting to $\$ 230,804.76$. Inasmuch as all the lines belonging to the city are being operated by the company and will continue to be so operated until 1907, it is impossible at present to draw any conclusions with reference to municipal operation.

In considering the municipal railway system of Cologne, it is necessary to distinguish between the distinctly urban and the suburban lines. During the first few years of municipal operation, especially in I90I and I902, the street railways of Cologne, as of all the cities of Germany, were affected by the general economic depression from which the country was suffering. The receipts were further reduced by the temporary disturbances of traffic caused by the change of equipment from horse power to electricity.

The fiscal year 190I-1902 showed a net loss of \$12,I45.54; in I902-I903 there was a net profit of $\$ 21.5 \mathrm{I}$; and in 1903-1904 a net profit of $\$ 130,816.06$. In considering this profit and loss account we must take into consideration that the city is compelled to pay to the street railway company an annuity of $\$ 3$ I4,319.15. During the last four years the city has been able steadily to reduce the operating expenses.

The city owns and operates three suburban lines, one to the neighboring town of Frechen, another to Königsforst, and a third to Ehrenfeld. Under the Prussian law any community operating railway lines occupies a legal position very similar to that of a 
private corporation. It may seek franchises from neighboring communities for the operation of such lines and is held to the same measure of obligation as a private company. In 1903 the city of Cologne entered into a contract with the town of Frechen to take over the line constructed in 1893 . Under the terms of the contract Frechen is to receive an annuity of $\$ 12,500$, which is to be increased annually by $\$ 250$ until it reaches $\$ 1_{5}, 000$. Cologne must furthermore pay into the treasury of Frechen one-third of

\begin{tabular}{|c|c|c|c|c|c|c|c|c|}
\hline & $1900-1901$ & & $1901-1902$ & & $1902-x 903$ & & $1903-1904$ & \\
\hline & $\begin{array}{c}\text { Gross } \\
\text { Receipts. }\end{array}$ & $\begin{array}{l}\text { Per } \\
\text { Car } \\
\text { Mile } \\
\text { Cts. }\end{array}$ & $\begin{array}{c}\text { Gross } \\
\text { Receipts. }\end{array}$ & $\begin{array}{l}\text { Per } \\
\text { Car } \\
\text { Mile } \\
\text { Cts. }\end{array}$ & $\begin{array}{c}\text { Gross } \\
\text { Receipts. }\end{array}$ & $\begin{array}{c}\text { Per } \\
\text { Car } \\
\text { Mile } \\
\text { Cts. }\end{array}$ & $\begin{array}{c}\text { Gross } \\
\text { Receipts. }\end{array}$ & $\begin{array}{l}\text { Per } \\
\text { Car } \\
\text { Mile } \\
\text { Cts. }\end{array}$ \\
\hline \multirow{2}{*}{$\begin{array}{l}\text { Receipts .... } \\
\text { Operating } \\
\text { penses .......... } \\
\text { Surplus ....... } \\
\text { Relation of } \\
\text { Operating Ex- Ex- } \\
\text { penses to Gross } \\
\text { Receipts (in } \\
\text { per cent.).... }\end{array}$} & $751,486.50$ & $204-5$ & $80 x, 350.75$ & 20 & $I, 021,433.00$ & $\overline{16 x-5}$ & $x, 249,536.75$ & $152-5$ \\
\hline & $\begin{array}{l}434,207.75 \\
317,278.75\end{array}$ & 12 & $\begin{array}{l}484,793.50 \\
316,557.25\end{array}$ & 12 & $\begin{array}{l}621,611.00 \\
299,822.00\end{array}$ & $\mid \begin{array}{lll}\mid x & x & -5\end{array}$ & $\begin{array}{l}706,46 x .25 \\
543,075.50\end{array}$ & $80-10$ \\
\hline
\end{tabular}

the net profits and has agreed to equip the line with electricity with the least possible delay. The line is of considerable importance for freight as well as passenger traffic; in fact, since I 900 the income from freight traffic has been more than double that from passenger traffic. The city authorities of Cologne were anxious to acquire the line because of its importance to the industrial growth of the city rather than the possibilities of profit involved. During the first year of municipal operation after paying the annuity of $\$ 12,500$ to the town of Frechen there remained a net profit of nearly $\$ 1, \infty 00$.

The second of the Cologne suburban lines, viz: from Cologne to Königsforst, is the first section of a network of suburban lines on the right bank of the Rhine which the city has decided to build. As this line passes through three towns-Kalk, Vingst and Merheimit was necesary first to enter into agreements with the local authorities of these towns. The agreements entered into are as follows:

First. In return for the use of its streets the town of Kalk is to receive an annuity depending on the net profits of the section running over its streets. It is provided, however, that in no case shall the annuity be less than $\$ 2,125$ nor more than $\$ 6,750$. 
Second. The town of Vingst received a lump sum of $\$ 1,250$ to be expended for certain street improvements, and in addition is to receive an annuity depending on the number of inhabitants, and graded as follows: $2 \frac{1 / 2}{2}$ cents per inhabitant per year as long as population remains under 10,$000 ; 33 / 4$ cents per inhabitant per year for population between 10,000 and 15,$000 ; 5$ cents per inhabitant per year for population between 15,000 and 19,$999 ; 61 / 4$ cents per inhabitant per year for population between 20,000 and 29,$999 ; 71 / 2$ cents per inhabitant per year for population over 30,000 .

Third. The town of Merheim granted the right to use one of its streets for $\$ 750$, a sum sufficient to make a few minor repairs.

The third suburban line operated by the city is intended mainly for freight traffic. The city is doing everything in its power to encourage the establishment of new industries. The Cologne-Ehrenfeld line was acquired mainly with a view to improving the freight connection with the state railways.

The city of Nürnberg did not come into full possession of its street railway system until June 6, 1903. During the brief period of municipal management the city authorities have shown a degree of business capacity which promises to place the system in the front rank of the German street railways. As soon as the city obtained complete control of the situation, the construction of the new lines which the city had fruitlessly attempted to obtain from the street railway company was begun. Before the end of August two of the main lines were extended into outlying wards. The influence of the improved service in relieving the congestion in the older portions of the city was immediately apparent. Two new lines to suburban towns were also begun without delay. The following year (1904) the belt line encircling the entire city was completed through the construction of a section connecting the terminals of two existing lines.

The financial results of the first two years of municipal operation have been satisfactory. It must be remembered that the street railway account is burdened with the interest and liquidation charges on the loan contracted for the cancelling of the company's franchise. This means an annual outlay for thirty years of about $\$ 138,000$. In spite of this fixed charge, the street railway department turned over to the general city treasury a net profit of $\$ 13,669.89$ in 1903 and $\$ 38,263.91$ in 1904. During the first year the expense per car mile was reduced from $13^{1 / s}$ cents to 12 cents. The percentage of total receipts expended for operating expenses was reduced from 48.7 
to 47.2 per cent. As regards economy of management the city can easily hold its own when compared with its predecessor. The street railway accounts under the two forms of management give ample evidence of this fact.

\section{(b) FARES.}

The most difficult problem confronting the cities which have embarked upon the municipal operation of street railways has been the adjustment of fares. During the last five years this question has been in the foreground of public attention. Unfortunately, the purposes and policies which the city authorities had in mind at the time the street railways were taken over have had to be considerably modified owing to the stern necessity of avoiding a deficit. In almost every instance one of the considerations which was of no small influence in bringing popular sentiment to favor municipal ownership and operation, was the possibility of so adjusting fares as to subserve social as well as financial ends. It was constantly pointed out that with municipal operation, the city would be able so to adjust fares as to influence the migration from the densely populated central wards to the outlying districts. Unfortunately the movement for municipal operation came at a time of economic depression in Germany, which was also felt in the street railway traffic. The first attempts to readjust fares with a view to influencing the distribution of population were followed by a marked decline in gross receipts. These two circumstances were immediately associated as cause and effect and led most of the cities to return to the system of fares in force prior to the period of municipal management.

The system of fares in force in German cities may be divided into two broad classes:

First. The uniform rate under which the same fare is charged no matter what the length of the ride.

Second. The zone tariff, $i$. $e$., a system under which the rate of fare increases with the length of the ride.

Prior to the period of municipal operation the zone tariff was practically universal. This system, although sound from the standpoint of the financial interests of the companies, had the serious inconvenience that it retarded the development of the suburban districts. In the agitation for municipal ownership much stress was laid 
on the possibility of introducing a uniform fare under municipal ownership. Of all the cities that have tried this system, Nürnberg is the only one that has been able to retain it. Munich, Düsseldorf, Barmen and Königsberg have tried it but felt compelled, for financial reasons, to revert to the zone system.

The experience of Munich is particularly instructive. As soon as the lines became the property of the city a radical revision of the system of fares was undertaken. A uniform rate of $21 / 2$ cents was introduced for all distances within the limits of the older city; a maximum distance of six miles. With this fare the right to one free transfer was given. Beyond the old city limits the fare was five cents with one free transfer. We have already had occasion to point out the heavy financial obligations of the city toward the street railway company which, combined with the fact that at the time of the beginning of city ownership, the community was in the midst of a period of financial depression, account for at least a portion of the deficit of the first few years. The municipal authorities felt that the uniform fare was at least one of the causes of the unfavorable showing. A commission was appointed which recommended that the uniform fare be retained at $21 / 2$ cents for week days, but that on Sunday the fare be increased to $33 / 4$ cents. It was furthermore recommended that commutation tickets be adjusted to the zone system. Monthly cards, valid for a distance not exceeding two miles, were to be sold for $\$ 1.25$, while cards permitting of a three mile ride were to cost $\$ 1.871 / 2$. This plan was put into operation in July, 1903, but did not fulfil the expectations of increased income. The number of persons using the cars on Sundays dropped from $10,408,833$ in 1902 to $6,933,450$ in 1903. The people evidently were unwilling to pay the higher Sunday rate. The question was again referred to a commission and in 1904 the city council decided to abandon the uniform fare and to substitute therefor a zone tariff. On October I6, I904, the new system went into effect. The lines were divided into sections called "units," each three-fifths of a mile in length. The rate of fare for each unit was fixed at $I \frac{1}{4}$ cents with a minimum fare of $2 \frac{1}{2}$ cents. The fare for the maximum distance was fixed at $61 / 4$ cents. Free transfers on all lines are issued. In order to make the change more acceptable to the working classes it was provided that from May Ist to October I $5^{\text {th }}$ the fare prior to $7 \mathrm{a}$. m., no matter what the distance, should be 
2I/2 cents, and from October I6th to April 30 th the same fare should obtain prior to $7.30 \mathrm{a}$. m. Monthly commutation tickets valid for a specified "two unit" ride (I I-5 miles) are sold for $\$ 1.50$, for a "four unit" ride, $\$ 3.00$. The holders of these cards may travel over these units as often as they desire. Monthly cards good for the entire system are sold for $\$ 3.75$.

During the first nine months of the new system the financial results have been relatively satisfactory. The gross receipts during this period increased $\$ 16,156.60$. Although the gross receipts were increased, the total number of passengers carried declined considerably. As compared with the nine months of the preceding year the decrease was nearly half a million $(458,626)$. Frankfort has also a zone tariff system similar in some respects to the Munich system. The gradation of fares is as follows:

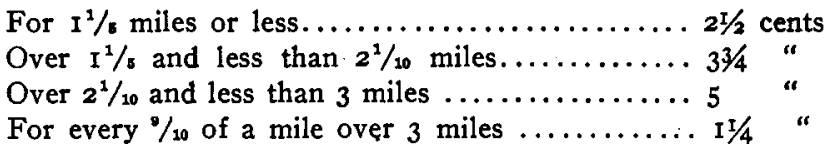

Frankfort has done more than any other German city to encourage the migration of population to the suburban districts. In 1904 a special system of fares was introduced for apprentices, workingmen and artisans whose income is less than $\$ 500$ per year. Cards for the six week days and entitling the holder to the single use of a section not exceeding one and four-fifth miles are issued for $71 / 2$ cents. These cards must be used before $7.30 \mathrm{a}$. m.; at least the ride must be begun before that hour. Weekly cards good for a morning ride before 7.30 and a return ride in the evening are issued for twenty cents. Monthly commutation cards for unlimited use of a section not exceeding one and fourth-fifth miles are also issued to workingmen for $\$ 1.25$. The city of Mannheim, imbued with the same desire to favor the housing of the working classes in the outlying districts, has adopted a plan which has proved most successful. Workingmen's ${ }^{7}$ tickets good for a two and one-tenth miles ride are sold for $I / 4$ cents, but these tickets can only be used from the suburban sections to the old city wall. A further ride must be paid at the regular rate.

In Bielefield special workingmen's cars are run during the early

These tickets are only sold to persons whose income does not exceed $\$ 300$ per year. 
morning and evening hours. The fare is $I / 4$ cents no matter how long the ride (maximum ride five and three-twenty-fifth miles). In Mühlheim a. d. Rohr workingmen's monthly commutation tickets are issued for $\$ 1.00$, good for the morning ride to and the evening ride from place of work. ${ }^{8}$

Cologne has recently introduced a new zone tariff system arranged as follows:

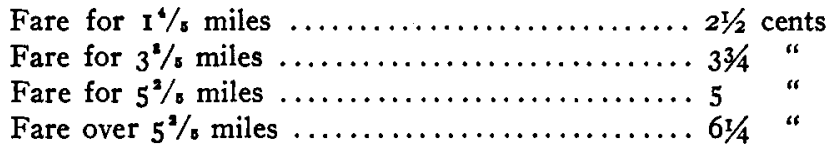

With every fare exceeding two and one-half cents a free transfer is issued. Four classes of tickets are sold:

First. For monthly tickets over the entire system, $\$ 3.25$.

Second. Monthly tickets over definite sections of the lines are arranged as follows: The entire system is divided into eighty-one "unit sections." The charge for monthly tickets over three contiguous sections is $\$ 1.25$, for five sections, \$r.75; for seven sections, $\$ 2.00$.

Third. In order to furnish workingmen with cheap transportation facilities, tickets good for use before 7 a. $\mathrm{m}$. in summer and before $7.30 \mathrm{a} . \mathrm{m}$. in winter are issued at the rate of six for seven and one-half cents.

Fourth. Tickets for school children are issued for one and one-quarter cents, good for any distance.

In Cologne, as in the other cities, holders of commutation tickets may use the lines as often as they wish. Nürnberg and Darmstadt are the only cities of any size which still retain the uniform fare in their municipal railway system. The fare is $2 \frac{1}{2}$ cents. In the issuance of commutation tickets Nürnberg has departed from the uniform rate. Monthly tickets for two mile sections are sold for \$1.50; monthly tickets for the entire system cost \$2.50. In Darmstadt the uniform fare of $2 \mathrm{r} / 2$ cents is only departed from on one line, on which the fare is $33 / 4$ cents.

The experience of some of the other cities in which the street railways are under municipal management is worthy of attention. Duesseldorf took over the street railways and immediately introduced the uniform fare of $2 \frac{1}{2}$ cents with right to one free transfer, and $33 / 4$ cents with right to two transfers. Monthly commutation tickets for the entire system were sold for \$1.50. A special rate of $\$ 1.00$ was made for school children. The first year of municipal

- Cf. Lindemann, op. cit. p. 273. 
operation showed a deficit of $\$ 33,963$. After careful consideration the city authorities decided to abandon the uniform fare and adopted a zone tariff. This seemed to have no immediate effect as the real cause of the deficit was the general economic depression. The attempt was then made to remedy the financial situation by diminishing the size of the zone unit. The increase in price, combined with the improvement in the industrial situation of the community placed the system on a paying basis.

In Barmen the uniform $2 \frac{1}{2}$ cent fare with free transfer was also introduced immediately after the municipalization of the street railways. Monthly commutation cards good for all portions of the system were issued at $\$ 1.25$. The maximum length of ride without transfer was four and one-fifth miles. Under this system the street railway accounts showed a chronic deficit amounting to $\$ 220$ in I897, $\$ 9,849$ in $1898, \$ 5,312$ in $1899, \$ 3,729$ in 1900 and $\$ 4,026$ in 1901. In December, I903, this system was replaced by a zone tariff under which the lines were divided into five zones of two and onetenth miles each. The rate for each zone was fixed at $I / 4$ cents with a maximum fare of $2 \mathrm{r} / 2$ cents.

In Königsberg the uniform fare system was in force during the first years of municipal management. In April, 1903, the city authorities, in order to increase the receipts, introduced a combination of the uniform rate and zone tariff. ${ }^{\circ}$ Within the limits of the city the uniform $2 \frac{1}{2}$ cent fare is retained, beyond the city limits $33 / 4$ cents is charged.

\section{Character of Service Under Municipal Management.}

It requires but very brief observation of conditions in German cities to be forced to the conclusion that "rapid transit" in the sense in which that term is used in American cities is unknown in Germany. Its absence has added greatly to the burdens of the municipal authorities, especially in increasing the difficulties of the housing and other sanitary problems. The failure to develop a system of rapid transit is not traceable to the shortcomings of municipal management. In fact, under municipal management conditions have undergone marked improvement. p. 266 .

'Cf. Lindemann. Wirtschaftspflege in der Deutschen Staedteverwaltung," Vol. ii 
The marked difference between American and Continental cities in the efficiency of the service is traceable directly to the conditions of business life. Until comparatively recent years there was no definite line of demarcation between the business and residence sections of German cities. This condition is directly traceable to the industrial characteristics of the mediæval city in which the artisan's workshop and residence were in the same building. Another factor of considerable importance is the relatively small area of the German as compared with the American cities. The incorporation of suburban districts which has taken place within the last ten years has greatly diminished the contrast, but the standards of traffic have not as yet caught up with the changed conditions. The system of urban transportation in Germany fails to meet the requirements of the great industrial centers that have developed in recent years. The street railway system has not advanced in harmony with the changes in urban conditions.

In most of the German cities the day cars are run at intervals of from four to eight minutes. On some of the most important lines the interval is reduced to three minutes, but more frequent traffic is unknown. After midnight the service is usually suspended until 5 a. $\mathrm{m}$. The speed of the cars is from one-third to one-half less than in the United States.

It is true that greater care is taken of the comfort of passengers, the number of persons permitted in each car being carefully designated. Nevertheless, this attention to detail is hardly counterbalanced by the absence of a well developed system of rapid communication which, by favoring a more equable distribution of population, would considerably simplify the most pressing municipal problems.

\section{Labor Conditions Under Municipal Management.}

One of the most notable achievements of municipal operation in Germany has been the betterment of labor conditions. The German cities undertook without delay to readjust the hours of labor so as to bring them within the ten-hour limit and so to arrange the schedules that this ten-hour service should be as continuous as possible. This constituted a great improvement over the older schedules under which the employees worked three and four hours at a time and 
were thus compelled to be on duty considerably beyond the ten-hour period. Compared with the United States the wages seem surprisingly low. In the larger cities of Germany the average wage of motormen is eighty cents per day, of conductors, seventy-five cents per day. In Cologne, conductors receive from $\$ 22.50$ to $\$ 30$ per month, motormen from $\$ 29.50$ to $\$ 37.50$, depending on the length of service. In case of disability arising from any cause whatsoever, an annuity of $\$ 175$ is assured during the period of such disability. Munich pays the motormen and conductors seventy-five cents per day, which is gradually increased until, after five years of service, the maximum rate of $\$ \mathrm{I} .25$ per day is reached. This represents the wage condition in most of the cities in which the street railways are under municipal management. The hours of labor in all the cities are adjusted on a ten-hour scale.

In judging this comparatively low wage scale, it must be borne in mind that the "fee" system still prevails in most of the German cities. Many of the passengers in paying their fare give to the conductors five pfennigs ( $\mathrm{I} / 4$ cents). The motorman is entitled to a certain percentage of the fees received by the conductor-usually about 35 per cent. In this way motormen and conductors receive from thirty to forty cents per day in addition to their regular wage.

Even with these additions the wage seems low compared with American conditions. The results ' of a special inquiry undertaken by the Census Bureau in 1902 show that 14 per cent. of the conductors on electric surface railways in cities of over 100,000 receive from $\$ 1.75$ to $\$ 1.99$ per day, 62.I per cent. receive from $\$ 2.00$ to $\$ 2.24$, and 13.6 per cent. receive from $\$ 2.25$ to $\$ 2.49$. Of the motormen, I 2.9 per cent. receive $\$ 1.75$ to $\$ 1.99,59.8$ per cent. receive from $\$ 2.00$ to $\$ 2.24$ and 19.8 per cent. receive from $\$ 2.25$ to $\$ 2.49$. Although, in Germany, the wage scale of street railway employees under municipal and private management is practically the same, there is considerable difference in the treatment of employees in case of sickness, disability or death. In all the German cities special funds have been established, towards which the city treasury contributes each year a sum equal to a certain percentage of the employees' salaries. Cologne and two or three of the other cities have even undertaken to build dwellings for their employees. 


\section{Comparison and Conclusion.}

Any attempt to determine the success or failure of municipal management of street railways in Germany must be based upon a comparison of public with private management. A careful review of the experience of German cities will show that private control has been singularly unprogressive. This has been due, in part at least, to the onerous conditions under which the original franchise grants were made. The companies did not feel justified in incurring the risks involved in making improvements on a large scale or in extending the service into the outlying districts of the city. Impressed with the lessons of this experience we find the more recent franchise grants specifying minutely the streets over which the service must be extended.

The relation between city and street railway corporations in Germany seems to be exactly the reverse of that in the United States. Here the companies are constantly seeking the right to extend their lines into new districts, whereas in Germany the municipal authorities are engaged in a constant struggle to secure from the companies an extension of the service. This difference in the attitude of the companies toward the extension of the service is due in part to the broader spirit of enterprise of American corporations, but the main reason is to be found in the fact that the German companies were aware that every new grant from the city would be accompanied by a demand for such a percentage of gross receipts as would considerably diminish their dividends. It is not surprising, therefore, that the German companies have shown a conservatism which is usually interpreted as lack of enterprise and inability to discount the future.

We have seen that the movement toward municipalization was largely determined by the antagonism between the cities and the street railway companies, growing out of the desire of the city to secure a more rapid extension of the service. If at the time they applied for the right to substitute electricity for horse power, the companies had more fully appreciated the value of the privilege, it is likely that they would have been more willing to accede to the wishes of the city authorities.

The process of municipalization was greatly facilitated by the fact that under the German law the accounts of public service 
corporations are subjected to careful public control. The amount expended by each company for the construction and equipment of the lines is easily ascertainable. Every dollar of capital represents actual investment. The total capitalization of the companies whose lines have been recently municipalized is as follows:

\begin{tabular}{|c|c|c|c|}
\hline & $\begin{array}{l}\text { Total capitaliza- } \\
\text { tion. }\end{array}$ & $\begin{array}{l}\text { Length of line, } \\
\text { including double } \\
\text { track railways. }\end{array}$ & $\begin{array}{l}\text { Capitalization per } \\
\text { mile of road. }\end{array}$ \\
\hline $\begin{array}{l}\text { Cologne Street Railway Co... } \\
\text { Nürnberg Street Railway Co. } \\
\text { Munich } \ldots \ldots \ldots \ldots \ldots \ldots \ldots \ldots\end{array}$ & $\begin{array}{r}\$ 1,368,625 \\
I, 570,000 \\
I, 500,000\end{array}$ & $\begin{array}{l}50.5 \\
29 \\
63\end{array}$ & $\begin{array}{r}\$ 27, \text { IOI. } 48 \\
54,138.28 \\
23,8 \circ 9.5^{2}\end{array}$ \\
\hline
\end{tabular}

The net capital liabilities per mile of track of the electric surface railways of the United States is $\$ 92,1$ I 4 . In the cities with a population of 500,000 and over, the net capitalization per mile of track reaches the enormous sum of $\$ 182,775$. In New York City ${ }^{10}$ the capitalization per mile of track is $\$ 259,542$; in Chicago, $\$ 109,537$; in Philadelphia, $\$ 165,085$; in St. Louis, $\$ 198,647$; in Boston, $\$ 97,353$; in Washington, $\$ 186,416$; in Pittsburgh, $\$ 185,170$, and in San Francisco, $\$ 140,985$.

The influence of this wide difference in capitalization on the expense account of street railway lines under American and European conditions is readily apparent. The percentage of total income expended by American companies for interest and liquidation charges and for the payment of guaranteed dividends to subsidiary companies is considerably larger than those of the German companies. The following table presents some data relating to Frankfort, Cologne and Munich. Accurate figures for the larger American companies are not obtainable:

\begin{tabular}{|c|c|c|}
\hline & $\begin{array}{l}\text { Interest and liqui- } \\
\text { dation charges. }\end{array}$ & $\begin{array}{c}\text { Percentage of } \\
\text { totai expenditure. }\end{array}$ \\
\hline $\begin{array}{l}\text { Frankfort } \ldots \ldots \ldots \ldots \ldots \ldots \ldots \ldots \ldots \\
\text { Cologne } \ldots \ldots \ldots \ldots \ldots \ldots \ldots \\
\text { Nürnberg } \ldots \ldots \ldots \ldots \ldots \ldots \ldots\end{array}$ & $\begin{array}{r}\$ 112,066.04 \\
204,000.00 \\
138,063.00\end{array}$ & $\begin{array}{l}10.6 \\
\text { I } 7.0 \\
28.7\end{array}$ \\
\hline
\end{tabular}

Any attempt to review the results of municipal ownership would be incomplete without some reference to the effect on the civic life

10 The net capitalization per mile of the 19.874 miles of track ( 131.13 operated by conduit trolley) controlled by the New York Interurban Company is \$494,399. 
of the communities under consideration. The introduction of electricity as a motive power greatly increased the possibilities of profit, and led the companies to exert the strongest possible pressure to secure a renewal of their franchises combined with the right to use electrical power. In the struggle to secure these new rights one can detect the first traces of the insidious forms of corruption which have done so much to undermine the civic life of American communities. In a number of instances, members of the council were retained as attorneys for street railway companies, and in one case an influential member of the "Magistrat" of one of the larger cities was made a director of a street railway company at a time when the company was seeking important privileges.

On the other hand, in those cities which have municipalized their street railway system, there is no indication of corruption traceable to the large increase in the number of city employees. The civil service system is so highly organized that the danger of political influence is reduced to a minimum.

Viewing the situation broadly, it may fairly be said that the municipalization of the street railways has protected these cities from the dangers involved in the desire of private corporations to secure control of local administration for the purpose of securing special privileges. In I 890 but few of the companies were declaring large dividends. In fact, the large return which they were compelled to make for the franchises under which they were operating grants made it necessary to exercise the greatest economy in order to make a fair profit on the capital actually invested. The new franchises, in offering to the companies far larger possibilities of profit, correspondingly increased the temptation to secure control of local policy. It is too early to predict whether the cities in which the street railways are still in the hands of private companies will be able to withstand the temptations which now beset them.

Are these lessons of German experience of any real value to our American municipalities? The answer to this question is a matter of far more than theoretical importance. Partly because of the feeling of irritation aroused by the corrupting influence of public service corporations on the civic life of American communities, but mainly owing to a general awakening to the possibilities of improved service in urban transportation and in gas and electric light service, 
the public mind is anxiously turning to municipal ownership and operation as a possible solution. In fact, indications are not lacking that we are drifting toward a fetichism of municipal operation which is likely to work great harm. One of the safeguards against this danger will be a proper estimate of the value of foreign experience.

The success of municipal operation in Germany means that the people are enjoying better service than under private management. The causes of the failure of private operation to meet modern requirements are readily ascertainable, and as we have seen these causes do not exist in the United States. In other words, the conditions for successful private management are far more favorable in the United States than in Germany.

Furthermore, as regards urban transportation, the requirements of public opinion as to the standard of service are immeasurably higher in the United States than in Germany. Notwithstanding our prodigality of public franchises, the American public has always set a relatively high standard as regards the character of the transportation service. We have been willing to pay a high, at times an exorbitant price, but there has been a corresponding demand for good service. No American community of any size would to-day tolerate the conditions of urban transit that obtain in most German municipalities. The present unrest of American public opinion is due to the fact that the requirements as to the standard of service are being raised with such rapidity that the over-capitalized corporations are unable to maintain the pace to which they have been forced during recent years.

Although the arguments in favor of municipal operation are being grouped about the possibility of large financial returns to the city treasury, it is not likely that this argument will stir the American people to any drastic measures. To secure united action, appeal must be made to the desire for improved service. The fact that municipal operation has given improved service in Germany does not necessarily mean that it will produce the same results in the United States. Whatever may be said against American street railway corporations, no one will deny that they have given far better service than the German companies. It is true that they have been given greater freedom in the development of the service and that the public demands, especially as regards rapidity of service, 
have been considerably higher than in Germany. Be this as it may, it is important to bear in mind that municipal operation in the United States would have to bear comparison with a higher standard of service than in Germany. Any attempt to apply the lessons of German experience which does not keep these differences in mind, is certain to be misleading rather than helpful. 